\title{
The impacts of bark harvesting on a population of Encephalartos transvenosus (Limpopo cycad), in Limpopo Province, South Africa
}

\author{
SAMUEL O. BAMIGBOYE ${ }^{*}$, M. PETER TSHISIKHAWE \\ Department of Botany, School of Mathematical and Natural Sciences, University of Venda. Thohoyandou 0950, South Africa. Tel.: +27-15-962 8881 \\ "email: reachtoba@gmail.com
}

Manuscript received: 11 October 2019. Revision accepted: 1 December 2019.

\begin{abstract}
Bamigboye SO, Tshisikhawe MP. 2020. The impacts of bark harvesting on a population of Encephalartos transvenosus (Limpopo cycad), in Limpopo Province, South Africa. Biodiversitas 21: 8-13. Cycads are the most threatened group of plants in the world and there are a wide range of ecological and anthropological forces responsible for the extinction risk of these taxa. South Africa is a global hotspot of cycad diversity and the country's cycads are facing high extinction risk. In this study, we sampled a population $(\mathrm{n}=34)$ of Encephalartos transvenosus Stapf \& Burtt Davy, a cycad species endemic to Limpopo Province, South Africa. The population was located on the Soutpansberg mountain range in the Thulamela Local Municipality. A survey was conducted to quantify the threats to the population. Forty-seven percent of the plants had been damaged by bark harvesting for traditional medicine, and the population showed a mortality rate of $9 \%$. We recommend further studies across a range of E.transvenosus populations to provide a broader understanding of impacts of harvesting and population trends. We also recommend community-based initiatives to enhance the protection of this species in the communities in which they are found.
\end{abstract}

Keywords: Bark, class distribution, conservation, cycad, population decline, threat

\section{INTRODUCTION}

The use of plant materials for traditional medicine is an ancient practice that has gained prominence in recent times (Fabricant and Farnsworth 2001; World Health Organization 2008, 2013, 2015). This has promoted much reliance on plant utilization with local trades of plant parts becoming a very lucrative business worldwide (Crouch and Smith 2011; Barata et al. 2016). This practice promotes indiscriminate harvest of several plant species resulting in an extinction crisis of certain plant taxa (Williams et al. 2013; Traffic International 2018). This makes continuous assessment of biological resources listed for medicinal purposes extremely important, especially taxa that are threatened. In South Africa, it is estimated that $60 \%$ of the total populace consult traditional healers and majority of these traditional healers use plant materials as medicine to cure various diseases in their clients (van Wyk et al. 2009). The trade of medicinal plants (muthi) in South Africa's markets, muthi shops and street vendors have enjoyed exponential growth due to high level of patronage (Botha et al. 2001; Dold and Cocks 2002; Mander 1997; Mander 1998; Williams 2003, 2007; Moeng 2010; Williams et al. 2013; Bamigboye et al. 2018).

Cycads are one of the most threatened groups of organisms globally (Hoffmann et al. 2010). Threats to cycads include illegal harvesting for horticultural purpose, harvesting for medicinal purpose, presence of invasive alien species, reproduction failure and climate change (Donaldson 2003; Mankga and Yessoufou 2017). The extinction risk of African cycads has increased over recent decades (Bamigboye et al. 2016). South Africa which harbors $70 \%$ of the continent's cycad species is also not immune to these threats (Golding and Hurter 2003), since there is currently a major cycad extinction crisis (Cousins and Witkowski 2017). Of the 38 cycad taxa indigenous to South Africa, 3 are classified as Extinct in the wild (Ex), 12 are Critically Endangered (CR), 4 are Endangered (EN), 9 are Vulnerable (VU), while 7 are Near Threatened (NT) and 3 are Least Concern (LC) (International Union of Conservation of Nature 2017).

Using repeated photographs to document changes in South African cycad populations, Okubamichael et al. (2016) discovered that cycads were declining more in Limpopo Province than in any other province in South Africa. This trend indicates that without any serious conservation interventions, the cycad species in Limpopo Province may experience ongoing population declines, with resultant local population extirpations and elevated extinction risk.

Unlike in other parts of the world where habitat destruction is a major threat to cycads, one of the main threats to South African cycads is harvest for traditional medicine (Donaldson 2006; 2010). Although South African cycads are protected (National Environmental Management Biodiversity Act (NE: MBA) 2004), the harvest of these taxa for medicinal purposes have been a continuous practice in South Africa (Donaldson 2003, 2006; Cousin et al. 2011, 2012, 2013; Williams et al. 2013, 2014; Williamson et al. 2016). Sixty-eight percent of South African cycads have been cited in literature as harvested for medicinal purposes and one species of cycad (Encephalartos woodii) is reportedly extinct due to harvest for traditional medicine (Donaldson 2009; Bamigboye et al. 
2018). The medicinal uses of cycads include treating stomach aches, stroke, heart attack (Ravele and Makhado 2009), high blood pressure (Ndawonde et al. 2007) and breast cancer (Bamigboye et al. 2017). The parts used for medicinal purposes are mainly roots, leaves, and bark (Ndawonde et al. 2007; Ravele and Makhado 2009; Bamigboye et al. 2017).

Encephalartos transvenosus Stapf \& Burtt Davy is a cycad species endemic to Limpopo Province (Goode 2001). It is protected under provincial and national legislation in South Africa (Limpopo Environmental Management Act (LEMA) 2004; National Environmental Management Biodiversity Act (NE: MBA) Act 10 of 2004). HiltonTaylor (1996) listed this species as rare although it is currently abundant in some places such as Modjadji Nature Reserve. With a total population of approximately 15,000 individuals, it is currently listed as a species of Least Concern (Donaldson 2009). Although this species is not classified as threatened, it is experiencing population declines due to habitat destruction and illegal collection (Donaldson 2009). Encephalartos transvenosus bark has been reported to be traded at muthi (traditional medicine) shops and street vendors in different districts of Limpopo Province (Moeng 2010; Tshisikhawe 2002; 2012). Other studies have also shown that the bark, leaves, and roots of E. transvenosus are currently being harvested for traditional medicine, hard drugs, and roofing material (Bamigboye et al. 2017).

In this study, we conducted a field survey to quantify the impact of bark harvest to a population of $E$ transvenosus and to also suggest conservation plan that can minimize illegal harvest of these species.

\section{MATERIALS AND METHODS}

\section{Study site}

The population surveyed was found at the entrance of the Mahunguwi village at the East facing slope within the Soutpansberg Mountain range in the Thulamela Municipality, Vhembe District, Limpopo Province, South Africa. The vegetation type of this area is Bushveld of savanna biome (Acocks 1998). The average rainfall of this area is $698 \mathrm{~mm}$ per annum (Samsam Weather Climate Tool 2016). The altitude of this mountain is from $25 \mathrm{~m}$ above sea level up to $1748 \mathrm{~m}$ of its highest western peak (Mostert et al. 2008).

\section{Study species}

Encephalartos transvenosus is a tall tree that can grow over $6 \mathrm{~m}$ in height (Goode 1989). It is regarded as one of the tallest and one of the fastest-growing cycads in South Africa (Ravele and Makhado 2009). It has broad leaves with network of veins (Jones 1993). The leaves are glossy and dark green in color (Giddy 1984). The leaflets of this plant are attached to the stalk (Dyer 1971). It grows on the mountains in Limpopo Province in South Africa (Ravele and Makhado 2009).

\section{Field survey}

An entire E. transvenosus population (n=34 individuals) located on this Mahunguwi village mountain was surveyed for this study. For each individual in this population, stem height, basal stem diameter, and crown damage were recorded. The number of dead and live individuals were also recorded. Out of the 34 individuals surveyed, 31 were alive and 3 were dead. Size-class distribution curve based on stem diameter was constructed for this population to assess its overall health, and to detect any possible impacts of harvesting. Stem height versus number of individuals curve was also constructed and compared with a similar curve that was plotted for $E$. transvenosus in Modjaji Nature Reserve as reported in Konings (2016).

Percentage of individuals that had suffered bark damage was determined and also quantified the extent of the damage by categorizing stems based on the percentage of their outer surface that had been damaged. Individuals with $5-30 \%$ damage, were categorized as mildly damaged, while individuals with $30-50 \%$ were considered "moderately damaged", and those with $>50 \%$ of the bark removed from their stems were classified as "severely damaged". Crown damage was also noted if individuals were affected by this.

\section{RESULTS AND DISCUSSION}

The size-class distribution based on basal stem diameter is bell-shaped curve. The result of basal stem size-class distribution showed lack of juveniles and young individuals (Figure 1), which is an indication of a population facing extinction risk (Ravele and Makhado 2009). Results on stem length versus number of stems (Figure 2) showed that there are fewer young individuals in the population sampled compared to the Modjaji population curve found in Konings (2016). Nine percent mortality (three dead individuals) was recorded (Figures 4-5) and $47 \%$ of the population suffered some degree of bark damage with $8.8 \%$ showing mild bark damage, $11.8 \%$ moderate damage and $26.5 \%$ severe damage (Table 1). Four individuals (11.7\%) suffered complete crown damage (Table 1; Figure 3). Eighty-seven percent of the total number of individuals that have suffered bark damage is between basal stem diameter size-class of $35 \mathrm{~cm}$ to $50 \mathrm{~cm}$ (Table 1). Majority of the highly and moderately damaged individuals (75\%) also fell into the size class of $40 \mathrm{~cm}$ to $45 \mathrm{~cm}$ basal stem diameter. These showed that majority of individuals that have suffered severe damage are within the middle class of this population.

Okubamicheal et al. (2016) on their estimation of cycads loss in South Africa discovered that the secondlargest factor responsible for cycads loss, based on repeated photograph study of South African cycads population, is harvest for traditional medicine. This showed that harvest of South African cycads for traditional medicine is a threat that is trending among South African cycads, in particular at Mphaphuli Nature Reserve in Limpopo Province, South Africa, where the majority of people indicated that the cycads were harvested mainly for medicinal purposes 
(Ravele and Makhado 2009). Bark harvest was the main threat found in the cycad population in this study, and this practice of bark harvest of cycads in South Africa have been reported in a number of previous studies (Donaldson 2006; Cousins et al. 2011, 2012, 2013; Williams et al. 2013, 2014; Bamigboye et al. 2017; Cousins and Witkowski 2017). From our observations, the dead individuals recorded in the population are attributed to bark harvesting as it exposes the plants to fungal infections (Figure 3). Size-class distribution of a population shows the reproductive capacity, recruitment, the probability of individuals in one class surviving to the next, and the ability of the population to survive ecological disturbances (Shaukat et al. 2012; Tshisikhawe 2012; Tshisikhawe and van Rooyen 2012). Lack of juveniles in this population might be due to ecological disturbance brought about by bark harvesting.

Table 1. Some of the parameters recorded on Encephalartos transvenosus individuals sampled in the study

\begin{tabular}{|c|c|c|c|c|}
\hline $\begin{array}{c}\text { Individuals } \\
\text { number }\end{array}$ & $\begin{array}{c}\text { Stem } \\
\text { height } \\
(\mathrm{cm})\end{array}$ & $\begin{array}{c}\text { Basal stem } \\
\text { diameter } \\
(\mathbf{m})\end{array}$ & $\begin{array}{c}\text { Stem } \\
\text { damage } \\
\text { category }\end{array}$ & $\begin{array}{c}\text { Crown } \\
\text { damage } \\
\text { (yes or no) }\end{array}$ \\
\hline 1 & 200 & 41 & A & No \\
\hline 2 & 270 & 45 & D & No \\
\hline 3 & 100 & 41 & $\mathrm{D}$ & No \\
\hline 4 & 350 & 54 & A & No \\
\hline 5 & 30 & 22 & A & No \\
\hline 6 & 550 & 57 & B & No \\
\hline $7 *$ & $\begin{array}{l}\text { Dead } \\
\text { individual }\end{array}$ & No record & No record & No \\
\hline 8 & 470 & 41 & $\mathrm{C}$ & No \\
\hline 9 & 200 & 38 & D & No \\
\hline 10 & 190 & 41 & $\mathrm{C}$ & No \\
\hline $11^{*}$ & $\begin{array}{l}\text { Dead } \\
\text { individual }\end{array}$ & No record & No record & No \\
\hline 12 & 420 & 45 & B & No \\
\hline 13 & 250 & 34 & $\mathrm{D}$ & No \\
\hline 14 & 190 & 35 & B & No \\
\hline $15^{*}$ & $\begin{array}{l}\text { Dead } \\
\text { individual }\end{array}$ & No records & No records & No \\
\hline 16 & 360 & 45 & $\mathrm{D}$ & No \\
\hline 17 & 230 & 29 & $\mathrm{D}$ & Yes \\
\hline 18 & 430 & 45 & $\mathrm{D}$ & Yes \\
\hline 19 & 350 & 38 & $\mathrm{D}$ & Yes \\
\hline 20 & 430 & 45 & $\mathrm{D}$ & No \\
\hline 21 & 520 & 45 & $\mathrm{C}$ & Yes \\
\hline 22 & 470 & 41 & $\mathrm{C}$ & No \\
\hline 23 & 500 & 51 & A & Yes \\
\hline 24 & 250 & 38 & A & No \\
\hline 25 & 350 & 32 & A & No \\
\hline 26 & 250 & 29 & A & No \\
\hline 27 & 480 & 35 & A & No \\
\hline 28 & 130 & 38 & A & No \\
\hline 29 & 280 & 48 & A & No \\
\hline 30 & 200 & 41 & A & No \\
\hline 31 & 250 & 48 & A & No \\
\hline 32 & 500 & 51 & A & No \\
\hline 33 & 200 & 38 & A & No \\
\hline 34 & 600 & 70 & $\mathrm{~A}$ & No \\
\hline
\end{tabular}

Note: *Dead individual. A. $0 \%$ of stem area affected by bark damage B. mild damage (5-30\%), C. moderate damage (30-50\%) and D. severe damage $(>50 \%)$

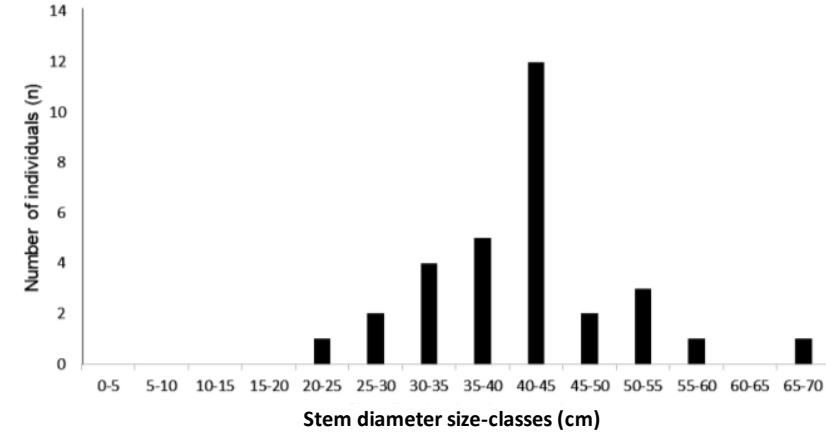

Figure 1. Stem diameter size-class distribution of a population of Encephalartos transvenosus in Mutale Municipality in Limpopo Province, South Africa

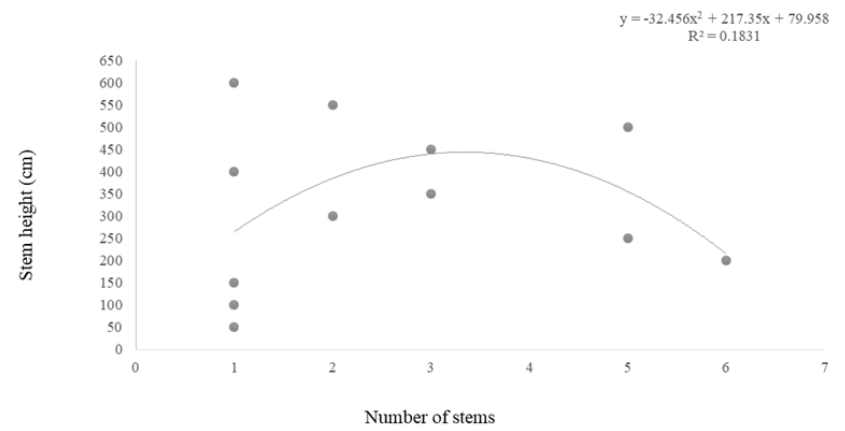

Figure 2. Correlation between stem height and number of stems for the population of Encephalartos transvenosus sampled in this study

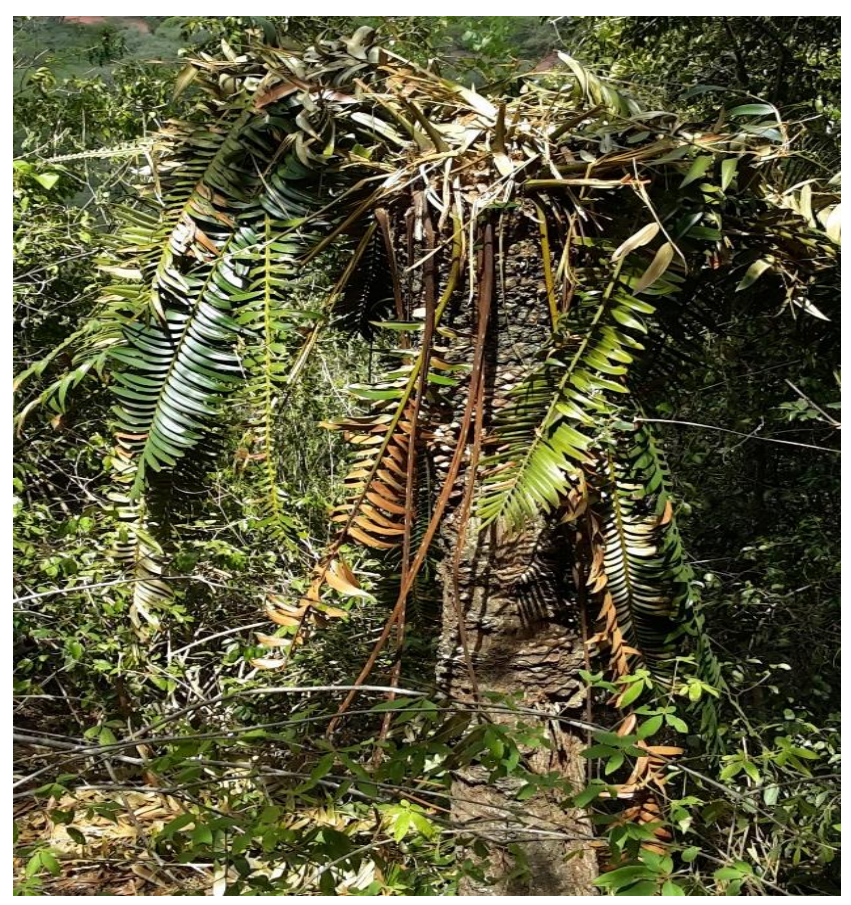

Figure 3. Crown damage on individual of Encephalartos transvenosus 


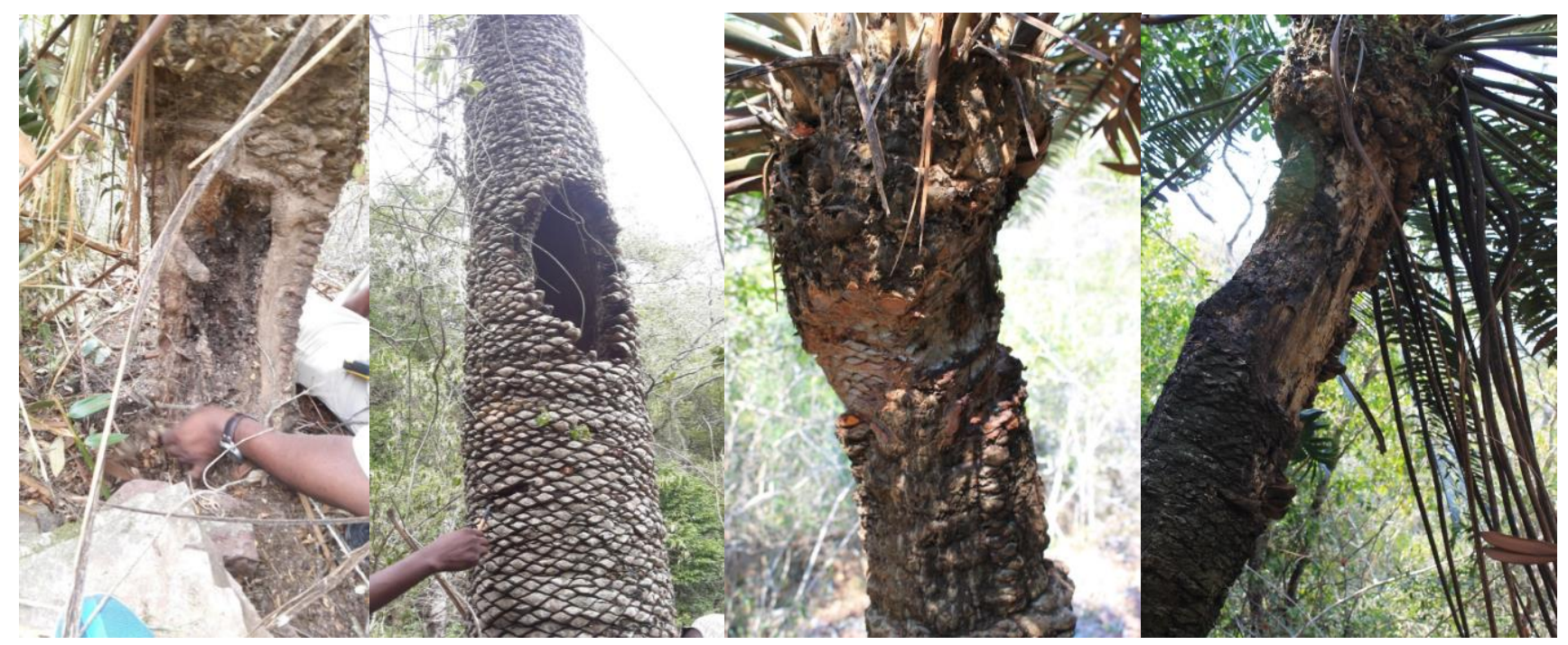

Figure 4. Bark damage to various Encephalartos transvenosus

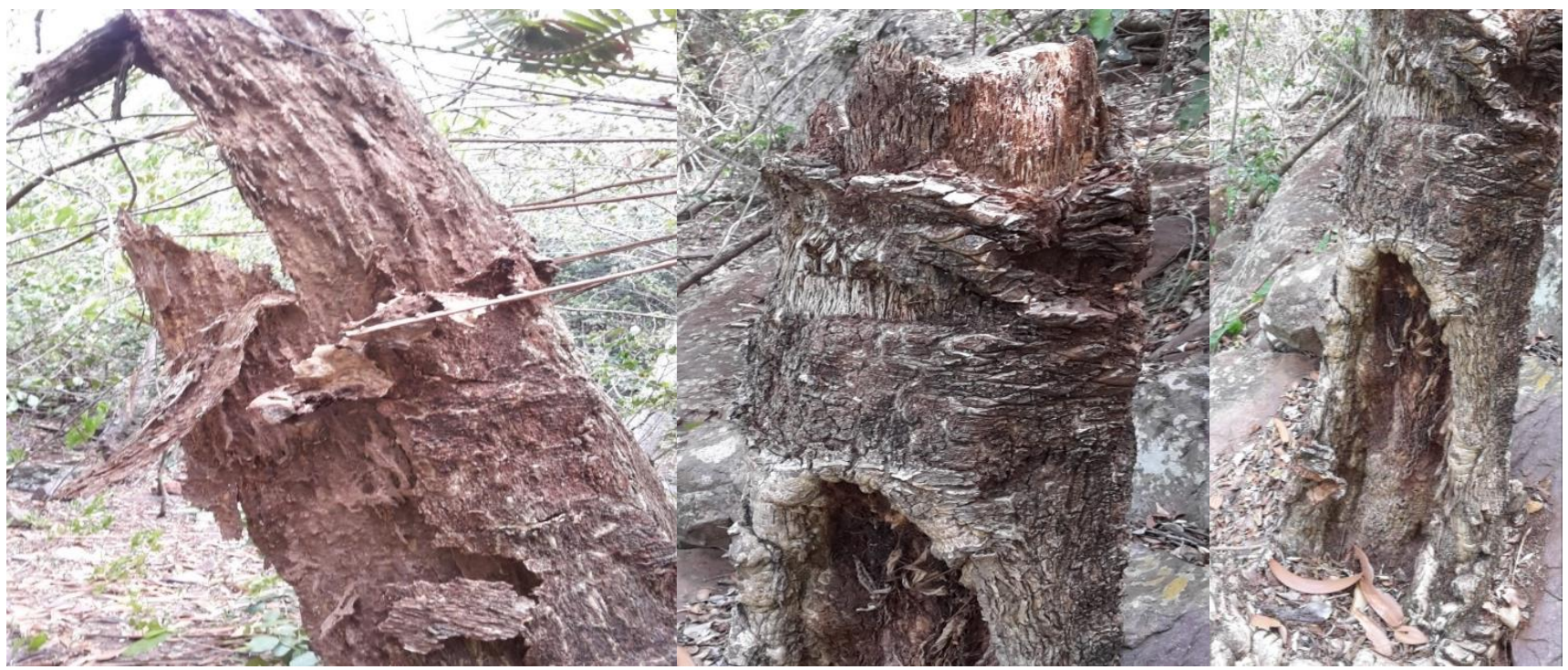

Figure 5. Dead Encephalartos transvenosus plants which suffered bark damage

Cycads have slow growth rate and exhibit poor recovery after a disturbance making these taxa vulnerable to extinction when they are collected for medicinal purposes (Donaldson 2003; Cousin et al. 2011: Cousin 2012). A size-class of $60.1-65 \mathrm{~cm}$ stem diameter, which should have some of the oldest individuals in this population, is totally missing $(\mathrm{n}=0)$ (Figure 1$)$. Absence of individuals in this size-class showed that there might be difficulties in these individuals persisting into the next class due to bark harvest which results in death of individuals. Harvest of middle-sized stems leads to absence of adult individuals in larger stem diameter classes hence leading to poor seed and poor regeneration that causes population decline (Luoga et al. 2004; McLaren et al. 2005; Makana and Thomas 2006; Bakali et al. 2017).
Since the Modjaji Nature Reserve has relatively younger individuals than the population we sampled in respect to stem height (Konings 2016), it can be concluded that harvesting of this unprotected population might have resulted in poor recruitment of young individuals in this population. In their study, Okubamicheal et al. (2016) showed that majority of cycad loss due to traditional medicine in South Africa occurred on communal lands. This revealed that less of this practice can be found in the Nature Reserves. Their study also supports that the practice of bark harvest of E. transvenosus found on the communal land sampled in this study might have affected this population negatively, resulting in poor recruitment of young individuals as compared to the ones in Modjaji Nature Reserve. 
Observations from this study revealed that the majority of individuals that have not yet been affected by bark harvesting in the population studied are located on the upper part of the mountain which is difficult to access. The relative inaccessibility of these individuals to harvesters likely prevented them from being exploited.

The possible causes of crown damage noticed in this study could not be ascertained, however, Ravele and Makhado (2009) noted that monkeys and baboons eat the cones and leaves of E. transvenosus. Destructive feeding by these animals may account for the crown damage noticed on some individuals in this population, as baboons were present on the mountain during the field survey, and individuals with crown damage have their leaves and cones completely destroyed (Figure 4). Crown damage may also be due to harvesting of leaves for roofing huts and decorations (Ravele and Makjado 2009; Bamigboye et al. 2017). Evidence of bark harvest was also observed on individuals that have suffered crown damage (Table 1). The combination of crown damage with bark harvesting will accelerate decline of this population. If these individuals cannot recover by producing suckers, the destruction of their crowns may lead to their eventual death.

In conclusion, the bell-shaped curve size-class distribution, as well as lack of juveniles and young individuals, exposed the cycad population in the study as vulnerable to extinction. In addition, continued bark harvesting and crown damage to E. transvenosus individuals could result in ongoing population decline and increased extinction risk. Therefore conservation efforts will need to be intensified in the areas where $E$. transvenosus occurs in order to prevent further population decline due to unsustainable harvesting. It is recommended that surveys of other E. transvenosus populations be conducted in order to determine the extent to which they are being impacted by harvesting for traditional medicine.

It is also recommended that plant taxa that are not threatened, have a better regeneration potential and have same medicinal value with cycads, be introduced to communities and muthi markets and shops in South Africa to be used in place of cycads. This approach might be needful as totally discouraging people from using these cycad taxa without providing alternative might not produce results due to the economic value that comes with trade of traditional medicine in recent times (Crouch and Smith 2011; Barata et al. 2016). This approach might also work effectively with consultations and in involvement of traditional healers in South Africa. These kinds of approaches uniquely applied might decrease wild harvest of South African cycads for medicinal purposes hence reducing the risk of extinction. It can, therefore, be concluded that community involvement conservation planning is non-negotiable planning that must be put in place and well implemented in curtailing illegal harvest of cycads for traditional medicine.

\section{ACKNOWLEDGEMENTS}

The authors wish to thank the Department of Science and Technology (DST) and the National Research Foundation (NRF) for providing funding through the South African Research Chair Initiative (SARCHI) for Biodiversity Value and Change at University of Venda, South Africa.

\section{REFERENCES}

Acocks JPH. 1998. Veld Types of South Africa. 3rd ed., Memoirs of the Botanical Survey of South Africa. No. 57, 1988.

Bakali M, Ligavha-Mbelengwa MH, Potgieter MJ, Tshisikhawe MP. 2017. Impact of ethnobotanical utilization on the population structure of Androstachys johnsonii Prain. in the Vhembe Area of the Limpopo Province, South Africa. Insights For Res 1 (1): 50-55.

Bamigboye SO, Tshisikhawe PM, Bonta MA. 2018. Review of extinction risks in South African cycads used for traditional medicine. South Afr J Bot 115: 279.

Bamigboye SO, Tshisikhawe PM, Taylor PJ. 2016. Review of extinction risk in African cycads. Phyton Int J Exp Bot 85 (1): 333-336.

Bamigboye SO, Tshisikhawe PM, Taylor PJ. 2017. Detecting threat to Encephalartos transvenosus (Limpopo cycad) through indigenous knowledge in Limpopo province, South Africa. Indian J Trad Knowl 16 (2): 251-255.

Barata AM, Rocha F, Lopes V, Carvalho AM. 2016. Conservation and sustainable uses of medicinal and aromatic plants genetic resources on the worldwide for human welfare. Ind Crops Prod 88: 8-11.

Botha J, Witkowski ETF, Shackleton CM. 2001. An inventory of medicinal plants traded on the western boundary of the Kruger National Park, South Africa. Koedoe 44 (2): 7-46.

Cousins SR, Williams VL, Witkowski ETF. 2011. Quantifying the trade in cycads (Encephalartos species) in the traditional medicine markets of Johannesburg and Durban, South Africa. Econ Bot 65 (4): 356370.

Cousins SR, Williams VL, Witkowski ETF. 2012. Uncovering the cycad taxa (Encephalartos species) traded for traditional medicine in Johannesburg and Durban, South Africa. South Afr J Bot 78: 129138.

Cousins SR, Williams VL, Witkowski ETF. 2013. Sifting through cycads: A guide to identifying the stem fragments of six South African medicinal Encephalartos species. South Afr J Bot 84: 115-123.

Cousins SR, Witkowski ETF. 2017. African Cycad ecology, ethnobotany and conservation: A synthesis. The Bot Rev 83: 152-194.

Crouch NR, Smith GF. 2011. Informing and influencing the interface between biodiversity science and biodiversity policy in South Africa. Bot J Linn Soc 16 (6): 301-309.

Dold AP, Cocks ML. 2002. The trade in medicinal plants in the Eastern Cape Province, South Africa. South Afr J Sci 98: 589-597.

Donaldson JS 2009. Encephalartos transvenosus Stapf \& Burtt Davy. National Assessment: Red List of South African Plants version 2015.1.

Donaldson JS. 2003. Cycads: A status survey and conservation action plan. IUCN/SSC Cycad Specialist Group, Gland, Switerland.

Donaldson JS. 2006. Preventing plant extinctions due to unsustainable international trade, SANBI Biodiversity Series 1. South African National Biodiversity Institute, Pretoria.

Donaldson JS. 2009. Encephalartos woodii Sander. National Assessment: Red List of South African Plants version 2017.1.

Donaldson JS. 2010. South African cycads face extinction crisis. http://www.sanbi.org/news/south-african-cycadsface-extinction-crisis.

Dyer RA. 1971. A further new species of cycad from Transvaal. Bothalia 10: $379-383$.

Fabricant DS, Farnsworth NR. 2001. The value of plants used in traditional medicine for drug discovery. Environ Health Perspect 109 (Supplement 1): 69-75.

Giddy C. 1984. Cycads of South Africa. Struik, Cape Town.

Golding JS, Hurter PJH. 2003. A Red List account of Africa's cycads and implications of considering life-history and threats. Biodivers Conserv 12: 507-528. 
Goode D. 1989. Cycads of Africa. Struik Winchester, Cape Town

Goode D. 2001. Cycads of Africa Volume I. D \& E. Cycads of Africa Publishers, Sandton.

Hilton-Taylor C. 1996. Red Data List of Southern African Plants. Strelitzia 4. South African National Botanical Garden, Pretoria.

Hoffmann M, Hilton-taylor C, Angulo A, Böhm M, Brooks TM, Butchart SHM, Carpenter KE, Chanson J, Collen B, Cox NA, Darwall WRT, Dulvy NK, Harrison LR, Katariya V, Pollock CM, Quader S, Richman NI, Rodrigues ASL, Tognelli MF, Vie JC, Aguiar JM, Allen DJ, Allen GR, Amori G. 2010. The impact of conservation on the status of the world's vertebrates. Sci New Ser 330: 1503-1509.

International Union of Conservation of Nature (IUCN) red list of threatened species. 2017. http://www.iucnredlist.org/.

Jones DL. 1993. Cycads of the World. Reed part of William Heinemann, Chats wood, N.S.W.

Konings KM. 2016. Life History Traits of South African Encephalartos spp. (Zamiaceae) and Their Implications for Understanding Population Structure, Responses to Threats and Effective Conservation Action. [Thesis]. University of Cape Town, Cape Town, South Africa.

Limpopo Environmental Management Act (LEMA). 2004.

Luoga EJ, Witkowskii ETF, Kevin B. 2004. Regeneration by coppicing (resprouting) of Miombo (African savanna) trees in relation to land use. For Ecol Manag 189: 23-35

Makana JR, Thomas SC. 2006. Impacts of selective logging and agricultural clearing on forest structure, floristic composition and diversity, and timber tree regeneration in the Ituri Forest, Democratic Republic of Congo. For Divers Manag 15: 1375-1397.

Mander M. 1997. Medicinal Plant Marketing and Strategies for Sustaining the Plant Supply in the Bushbuckridge Area and Mpumalanga Province, South Africa. Department of Water Affairs and Forestry, Pretoria.

Mander M. 1998. Marketing of Indigenous Medicinal Plants in South Africa: a Case Study in KwaZulu-Natal. Food and Agriculture Organization of the United Nations, Rome.

Mankga LT, Yessoufou K. 2017. Factors driving the global decline of cycad diversity. AoB PLANTS. 9. plx022. DOI 10.1093/aobpla/plx022

McLaren KP, McDonald MA, Hall JB, Healey JR. 2005. Predicting species response to disturbance from size class distributions of adults and saplings in a Jamaican tropical dry forest. Plant Ecol 181: 69-84.

Moeng ET. 2010. An Investigation Into The Trade of Medicinal Plants by Muthi shops and Street Vendors in The Limpopo Province, South Africa. [Dissertation] School of Molecular and Life Sciences, Faculty of Science and Agriculture, University of Limpopo South Africa.

Mostert HCT, Bredenkam GJ, Klopper HL, Verwey C, Mostert RE, Hann N. 2008. Major vegetation types of the Soutpansberg Conservancy and Blouberg Nature Reserve. South Africa. Koedoe 50: 32-48.

National Environmental Management Biodiversity Act (NE: MBA) 2004.

Ndawonde BG, Zobolo AM, Dlamini ET, Siebert SJ. 2007. A survey of plants sold by traders at Zululand muthi markets, with a view to selecting popular plant species for propagation in communal gardens. Afr J Range Forage Sci 24 (2): 103-107.
Okubamichael DY, Jack S, De Wet Bösenberg J, Hoffman MT, Donaldson JS. 2016. Repeat photography confirms alarming decline in South African cycads. Biodivers Conserv 25: 2153-2170.

Ravele AM, Makhado RA. 2009. Exploitation of Encephalartos transvenosus outside and inside Mphaphuli Cycads Nature Reserve, Limpopo Province, South Africa. Afr J Ecol 48 (1): 105-110.

Samsam Weather Climate Tool. 2016. http://www.samsamwater.com/ climate/climatedata.php?lat $=-22.74782 \& \operatorname{lng}=30.62988 \& l o c=$ Tshitavha\% $2 \mathrm{C}+$ South+Africa

Shaukat SS, Aziz S, Ahmed W, Shahzad A. 2012. Population structure, spatial pattern and reproductive capacity of two semi-desert undershrubs Sennaholosericea and Fagoniaindica in Pakistan. Pak J Bot 44: 1-9.

Traffic International. 2018. Therapy for Medicinal Plants. http://www.traffic.org/medicinal-plants/

Tshisikhawe MP, van Rooyen MW. 2012. Population biology of Brackenridgea zanguebarica in the presence of harvesting. J Med Plant Res 6 (46): 5748-5756.

Tshisikhawe MP. 2002. Trade of Indigenous Medicinal Plants in The Northern Province, Venda region: Their Ethnobotanical Importance and sustainable use. [Thesis]. University of Venda for Science and Technology, Thohoyandou, South Africa.

Tshisikhawe MP. 2012. An Ecological Evaluation of The Sustainability of Bark Harvesting of Medicinal Plant Species in The Venda Region, Limpopo Province, South Africa. [Dissertation]. University of Pretoria, Pretoria, South Africa.

Van Wyk BE, van Oudtshoorn B, Gericke N. 2009. Medicinal Plants of South Africa. Briza, Pretoria.

WHO. 2008. Traditional medicine. Factsheet No. 134. Revised December 2008. World Health Organization, Geneva, Switzerland

WHO. 2013. Traditional Medicine Strategy 2014-2023, World Health Organization, Geneva, Switzerland

WHO. 2015. Connecting global priorities: biodiversity and human health: A state of knowledge review. World Health Organization, Geneva, Switzerland.

Williams VL, Cousins SR, Witkowski ETF. 2014. From fragments to figures: Estimating the number of Encephalartos stems in amuthi market. South Afr J Bot 93: 242-246.

Williams VL, Victor JE, Crouch NR.2013. Red listed medicinal plants of South Africa: Status, trend and assessment challenges. South Afr J Bot 86: 23-35.

Williams VL. 2003. Hawkers of health: An investigation of the Faraday Street Traditional Medicine Market in Johannesburg, Gauteng. Plant Ecol Conserv Series No. 15. Unpublished report to the Gauteng Directorate for Nature Conservation, DACEL, Johannesburg.

Williams VL. 2007. The Design of A Risk Assessment Model to Determine The Impact of The Herbal Medicine Trade on the Witwatersrand on Resources of Indigenous Plant Species. [Dissertation]. University of the Witwatersrand, Johannesburg.

Williamson J, Maurin O, Shiba S, Van der Bank H, Pfab M, Pilusa M, Kabongo R, Van der Bank M. 2016. Exposing the illegal trade in cycad species (Cycadophyta: Encephalartos) at two traditional medicine markets in South Africa using DNA barcoding. Genome 59 (9): 771-781. 